\title{
A site of transnationalism in the "Ungrounded Empire": Taipei as an interface city in the cross-border business networks
}

\author{
Jinn-yuh Hsu \\ Department of Geography, National Taiwan University, 1 Roosevelt Road, Section 4, Taipei 106, Taiwan
}

Received 9 September 2003; received in revised form 10 November 2004

\begin{abstract}
This paper explores the dynamics of the economic development of Taipei City under conditions of globalization. Although Taipei City had undergone rapid industrialization and exploited the rural-urban division of labor since at least the 1960s, the city's economic base changed dramatically after 1980. Initiating a process of industrial restructuring, the nation state encouraged high technology industries to help upgrade Taipei City's role within global production chains. It was the transnational connection that kept regional growth within high 'value-added' activities. Instead of relying on a few major transnational corporations as the key agents of internationalization, Taipei City transformed itself into a node for high-technology knowledge, which connected the city with high-technology hubs elsewhere, and to Silicon Valley in particular, through transnational technical communities. At the same time, companies headquartered in the city extended their production chains across the Taiwan Strait to locate production facilities in the major coastal cities of mainland China. In consequence, Taipei City became a nodal city in these cross-border connections. These developments illustrate the limits of global city discourses which fail to pay sufficient attention to the role of developmental states and transnationalism in the process of global transformation.
\end{abstract}

(c) 2004 Elsevier Ltd. All rights reserved.

Keywords: Taipei City; Interface city; Global city; Transnationalism; Cross-border business networks

\section{Introduction}

In the current global economy, cities have become the key locations that connect national economic activities with the broader world economy. Scott $(1998,2000)$ has argued that major cities and their surrounding region, or city-regions, are the engines of the global economy. Sassen (2001) has even claimed that it is global cities, not national economies, that should be at the core of discussions about the global system.

Taipei, the capital city of Taiwan, is no exception. However, analyses of the development of the postwar Taiwanese economy, has rarely taken the city's role seri-

E-mail address: jinnyuh@ntu.edu.tw ously. Most of this work has focused upon role of the interplay between state intervention and market formation in national economic development (see Wade, 1990; World Bank, 1993). However, as Short (1996), Lo and Marcotullio (2000) and Byrne (2001) have argued, urban and economic worlds co-evolve and create divergent roles for cities within the economic transformation process. In light of such debates, this paper aims to explore Taipei City's economic bases within the globalization process. In the last two decades, Chinese transnationalism has become a distinctive domain within the new global capitalism of the Asia-Pacific region, and a worldwide ethnic Chinese network has emerged as a key issue in managing economic development in the 'great China circle', which includes Hong Kong, Taiwan and China (Mitchell, 2000; Ong and Nonini, 1997; Kao, 1993). Key questions here are: how this ethnic 
connection effects the process of globalization in the major East Asian cities in general, and in Taipei City in particular? and; what role is played by Taipei in the seemingly "ungrounded empire" of ethnic Chinese capitalism?

By attacking these issues, this paper will be able to provide a case for the East Asian urban world. The current literature considers cities such as Seoul (Short and Kim, 1999), Singapore (Yeung and Olds, 2001), Hong Kong (Yeung, 2000), emerging world cities in China, such as Shanghai (Wu, 2000), Shenzhen (Cartier, 2002), and Beijing (Zhou and Ma, 2000), and Tokyo (Sassen, 2001). However, to date the literature has bypassed Taipei (see Sassen, 2002), a $\gamma$-level city in the globalization and world city network studies (Taylor et al., 2000).

The paper will deal with the role of Taipei in the globalization process in general, and cross-border ethnic business networks in particular. In Section 2 of the paper, I develop a theoretical framework suitable for addressing the issues that surround the globalization of cities and processes of transnationalism. This part of the paper suggests that Taiwan performs an 'interface' role within trans-border economic networks. In Section 3 , the paper demonstrates that the economic bases of Taipei City evolved from trading services associated with rural industrialization in 1970s, which underwent economic restructuring after the mid-1980s. Section 4 points out the new context of globalization for Taipei City after 1990. Section 5 considers Taipei's new role as an interface city that is connected to both Silicon Valley and China's coastal cities, and to Shanghai in particular. Section 6 discusses the co-ordination and regulation issues caused by the political tensions associated with such cross-border investments. Section 7 addresses a number of governance issues relating to the political impasse across the Taiwan Strait, which casts a shadow over Taipei City's long run development. Finally the paper concludes by reflecting on the global city debate and identifies two flaws in the roles attributed to the developmental state and transnationalism.

\section{Theoretical framework}

\subsection{Globalization and cities}

Economic globalization takes divergent shapes in different time-space contexts. It usually refers to the increasing volume of trans-border flows of goods, capital, and people, which is made possible by a lowering of institutional barriers (Castells, 1996; Held et al., 1999). Evidence can also be found in the international trade between regions due to the geography of comparative advantage (inter-firm trade), or in the geographical dis- persal of the linked components of the global production networks (intra-firm trade). For a number of economic geographers, globalization means the rise of multinational corporations and their global distribution of direct investments (Dicken, 1998; Knox and Agnew, 1998). Globalization also includes global financial architecture, which has become the dominant force in framing the global capitalist system and its landscape (Martin, 1994; Sassen, 2001). The rise of global production chains has had a significant impact on the evolution of cities. They have enhanced the function of services and, above all, producer services, in the core cities to facilitate globalization. In global networked systems, the organization of control and command from a few nodes to integrate and coordinate their development is imperative (Daniels, 1993). Among these nodes, a number of major cities and regions have emerged to become the sites of regulation and governance. All in all, localities, regions, and nations are under the shadow of globalization, no matter whether they are actively participating or forcedly incorporated in the system. Inter-city competition in the global economic system will become fiercer and more direct, as protection from the national state will wither (Scott, 2000). Unless they are regional nodes within global flows, cities will no longer prosper and survive in the ruthless race of global economic competition.

How can cities grow as the nodes of global flows? Many recent accounts of local competitiveness have offered interpretations rooted in the role of the social in shaping the economic activities (Storper, 1997; Sunley, 2000). Each region and city has to utilise collaboration among constituent firms, institutions and agents, and extend its webs of interaction with translocal forces to avoid over-competition and lock-in. Building up a collective order has become an important step towards achieving regional economic development, since both coherence and flexibility could exist simultaneously only if clear game rules are set and followed by the members. It is particularly critical to urban and regional development in the learning-based new economy, which emphasizes the role of interactive learning in constructing competitive advantage in the world economy (Hall, 2000; Lambooy, 2002). In this sense, the recent diffusion of knowledge cities and learning regions has been promoted by analysts of the knowledge economy (Scott, 1998; Cooke, 2001).

The 'winners' in the globalization 'race' are usually thought to be world cities, global cities, or global command and control centers, which serve to integrate and coordinate the globalized economy (Sassen, 2001). However, under such circumstances, most cities, such as Taipei City, disappear off the global map (Robinson, 2002). There is, therefore, a need for an alternative concept to examine the dynamics behind these "hidden" cities in the globalizing process. 


\subsection{Transnationalism and the interface city}

In fact, globalization should not be understood as the exclusive preserve of big capitals and hegemonic states, but as a process which allows ordinary people to cross territorial boundaries to constitute an organizational field that connects home and host regions. As argued by Low (1997), globalization, even in the economic sphere, is an arena for the restructuring of networks of flows (of money, goods, and people) and of their interaction in various geographical scales, from local, through regional, to global. Glick Schiller et al. (1992, p. 52) have defined transnationalism as "the processes by which immigrants build social fields that link together their country of origin and their country of settlement". The operation of social networks from below, through the mechanisms of transnational migration, would tackle the issue of the articulation of people's everyday lives (both of elites and ordinary ones) with the macro forces of socio-cultural and political-economic institutions in different geographical scales (Smith, 2001). Smith (2001) has suggested that the globalizationlocalization process articulated in the global city is manifested in "transnational social space" through the agency of "transnational migrant networks" in particular. Among these networks, the transnational connection made possible by a community of people, whether elite or refugees, would be the key agent in the emergence of transnationalism. Particularly relevant to the current study, the international migration of skilled people was identified as a key factor in cross-fertilizing both sending and hosting cities as they travelled back and forth within highly specific knowledge and professional networks (Beaverstock, 2002).

Although distinct from "globalization from above", transnationalism does not undermine the role played by the state in controlling borders and regulating migration (Waldinger and Fitzgerald, 2004). Transnational social relations are usually anchored in, while also transcending, one or more nation-states. Transnationalist discourses insist on the continuing significance of national borders, state policies and national identities, while simultaneously crossing over them, and constituting a hybrid social space. Instead of maintaining a kind of zero-sum assumption of exclusiveness of nation states and globalization, the transnationalist discourses sees them as engaging in a process of mutual construction (Smith, 2001).

Among the studies of transnationalism, the case of the Chinese diaspora attracted particular attention. It was argued that the diasporic Chinese constituted an "ungrounded empire" which connects different places into a worldwide business network (Ong and Nonini, 1997). This network often stretched successfully across regional and national boundaries (Mitchell, 2000). Within the network, kinship and guanxi (interpersonal relationship) lubricated trans-border business transactions and facilitated the construction of the business empire within a turbulent economic world (Redding, 2002).

This transnational ethnic community usually bridged regional economies and encouraged flows of information, capital, people and their embodied knowledge within the ungrounded empire. Each locality is bounded within an ethnic network, and recombined to create new business firms, new industrial practices, and new economic geographies. The process of interlinking among the nodes of the ethnic web constitutes the organizational and geographical forms of transnationalism. Some cities and regions gained growth momentum, while others failed and declined. However, it did not mean that the potential of each city or region would be determined by the external connections. In contrast, this paper argues that the current process of globalization provides both a challenge but also opportunities. The outcome depends on how each locality takes advantage of strategic nodal position in the territorial division of labor; did they respond to the challenge with active policies, or did they passively withdraw from the opportunities that emerged? Therefore, each city had to build up close connections with other nodes in the global network, while enhancing its own competitive advantage in absorbing external resources. In this sense, the ungrounded empire became grounded in particular cities (Zhou and Tseng, 2001). Cities such as Hong Kong and Taipei, or even parts of cities, such as "Little Taipei" in Los Angeles (Zhou and Tseng, 2001), performed nodal roles in worldwide ethnic business networks. They were, in other words, interface cities.

Gereffi's (1995) analysis of triangle manufacturing, proposed a role for semi-peripheral manufacturers to move from being direct suppliers for the US market to becoming "middleman" in the production chains. The essence of triangle manufacturing is that US, or other overseas, buyers place their orders with Newly Industrialized Country (NIC) manufacturers, such as Taiwanese and Korean OEM (original equipment manufacturing) firms, who in turn shift some or all of this production to affiliated offshore factories in low-wage countries in the Southeast Asia or China (Gereffi, 1995, p. 118). By doing so, intermediate manufacturers could move up the ladder of global value chains.

However, the concept of the interface city goes beyond the 'middleman region' in Gereffi's model. It opens up the possibility of "globalization from below", as the firms - particularly large multinationals - are not necessarily the key agents in the connection between the three regions. As demonstrated by Portes (1998), transnational immigrant communities often actively bridge donor and host regions, and constitute a complementary circuit for flows of capital, information and people. More often, a transnational technological community can provide an alternative and potentially more flexible 
and responsive mechanism for long distance transfers of skill and know-how, particularly between very different business cultures or environments (Coe and Bunnell, 2003). In this sense, the interface city presents another kind of global city, which should not be confined exclusively to the domain of corporate headquarters (cf. Taylor et al., 2000).

Against such understandings, what elements constitute an interface city? Three factors are particularly important. Firstly, the interface city should possess complementary assets in order to collaborate with other cities. In economic terms, the industrial structure of an interface city should be open and focus on one or more segments of production chain and allow itself to engage in the global division of labor. Incorporation within such chains provides the interface city with opportunities to assimilate and absorb knowledge and technology from more 'advanced' cities. The external links induced from the collaboration between different cities or regions are unavoidable for an interface city.

Secondly, in order to act as middleman, the interface city has to upgrade its own governance capability to coordinate and integrate the production chains. In countries with strong traditions of state intervention, such as the East Asian NIC, global forces do not necessarily weaken the state's function in "correcting" the disordered market, and improving its global competitiveness (Yeung and Olds, 2001). Upgrading added value in local production networks and obtaining the 'higher' functions in international value chains has become imperative for East Asian states. Moreover, nation states can enhance the competitive advantage of their cities by attracting trans-border investments (Yeung and Olds, 2001; Hill and Kim, 2000).

Third, and finally, the key to the success of the interface city resides not only in top-down state intervention, but also in the development of bottom-up social networks. The interface city should acquire a social dimension that renders cross-border transactions effective. Rather than taking the large corporation as the major actor (Dicken, 1998), this paper adopts a network approach and focuses on the social embeddedness of the profit-oriented business world. It conceives of the global system as a network of regional worlds (Scott, 1998). Within this network-governed economy, social ties and cultural affinity between communities within regions are a central concern. The knowledge-based economy requires close social ties to identify the "right" people, and thus the "right" technologies, to ensure the transfer of embodied tacit knowledge. The interface city usually becomes a place of transnationalism to attract diverse flows of talent to render globalization from below possible.

One concern arises here on the difference between the interface city and the category of the 'gateway city' to which Taipei City was allocated by the GaWC (Globalization and World Cities Group and Network) research group. The founder of the group, Peter Taylor, has argued that Taipei City belongs to a subgroup of "highconnectivity gateways" which were "the places where many firms decided they had to be". Beyond those were global cities that possessed command functions (Taylor, 2004, p. 92). ${ }^{1}$ Two distinctions could be made between these two city types. Firstly, gateway cities are shaped by the key corporations who wish to take advantage of their location to explore connected markets. In contrast, interface cities are predominantly sites of transnationalism with rich textures of cross-border social communities. Secondly, while gateway cities, such as Hong Kong, focused on providing producer services for cross-border trade, interface cities could play a pivotal role in the value creation in triangle manufacturing.

The network approach to globalization has focused on the role of ethnic ties in particular to explain the accelerated growth of cross-border economic transactions (Kao, 1993; Dicken and Yeung, 1999). Ethnic ties render the utilization and coordination of resources among firms of the cross-border regions flexible and economical, hence reinforcing their competitiveness (Kotkin, 1992; Kao, 1993; Borrus, 1997; Mitchell, 2000). However, the interface city encountered the danger of becoming an ethnic enclave in exploiting the ethnic advantage.

No doubt ethnic ties and interpersonal relationships can facilitate collaborations and reduce the uncertainty of economic deals. Shared language and cultures can also help producers - even those located at great distances-gather information about people, capital and other resources within the community (Wong and Salaff, 1998). In other words, such social ties fulfill the need of "know-who" in the learning economy in which the social dimension is the key and often ignored issue in the constitution of competitiveness (Lundvall, 1996).

However, as Burt (1992) illustrated in his arguments about the role of the "structural hole" in the process of network expansion, within worldwide ethnic business networks, the interface node could play its role only if there were weak direct links between the other two parts or the city could provide non-redundant assets to enhance the interaction between them. ${ }^{2}$ Accordingly, the development of the interface city would be seriously challenged in three situations. Firstly, the case of insufficient infrastructures, in both institutional and physical aspects, to support and maintain the connections, would lead to contacts becoming costly and inefficient. Secondly, and

\footnotetext{
${ }^{1}$ In fact, most of the GaWC literature merely included Taipei City in their world city statistics or figures, without detailed discussion. Even in Taylor (2004), "Taipei" appeared 10 times, but only once was found in the text, and the others in tables or figures.

${ }^{2}$ These non-redundant contacts were disconnected in some wayeither directly in the sense of no direct contact with one another, or indirectly in the sense of one having contacts that excluded the others (See Burt, 1992).
} 
more seriously, the interface node could be crowded out as direct links between its connection nodes develop - as a process this is supposed to be relatively easy within ethnic networks. In this case, the interface node would evaporate, unless it could upgrade its supportive role to create new connections. Thirdly, the interface city may stifle itself with over-social embeddedness, particularly through close ethnic ties. While the ethnic enclave is a 'good' strategy for survival, it is a 'bad' arrangement for global competition. Zhou (1992) demonstrates that the abundance of cheap ethnic labor in New York's Chinatown removes a stimulus for innovation among local producers. The ethnic buffer developed to protect from outsiders can too easily become the insulation from new ideas. Dense ties grow too dense to be broken for new ties, undermining the ability to the balance of coupling and decoupling needed for economic success within ethnic networks (Granovetter, 1995). By the same token, the vibrant spaces of diverse cities can serve as powerful magnets for highly skilled workers and investors attracted to the quality of urban life. Besides providing qualified amenities, the interface city has to tolerate the diversity and heterogeneity of social capital so that it can increase the chances of innovation (Florida, 2002).

\section{Rural industrialization and the rise of post-industrial city in 1970s}

Taiwan emerged as a newly industrializing country in the early 1960s to occupy a role of export processing in the new international division of labor (Frobel et al., 1980; Wade, 1990). In this process of development, the key agents were not large conglomerates (mostly state owned), but a wide array of small and medium sized enterprises (SMEs) in labor intensive industries such as plastics, textiles, foods and footwear (Levy and Kuo, 1991; Mody, 1990). ${ }^{3}$ As shown in Table 1, over 99\% of the industrial establishments were SMEs, and employed less than 10 people. According to the Ministry of Economic Affairs, SMEs were responsible for more than $65 \%$ of the export value from 1960 s on. It was no exaggeration to assert that SMEs constituted the pillars of Taiwan's postwar economic miracle (Orru, 1991; Zhou, 1999). ${ }^{4}$

\footnotetext{
${ }^{3}$ In most cases, the conglomerates monopolized the production of intermediates for the downstream SMEs. These SMEs procured inputs from the former and exported the final goods overseas. In some cases, the improvement in the production efficiency of the conglomerates would benefit the comparative advantage of the exporting SMEs (Amsden, 1985).

${ }^{4}$ Here I am not arguing that the SMEs matched the rosy picture of flexible specialization and craft democracy, as in reality they were full of self exploitation and labor abuse in the labor intensive SMEs, as shown by Shieh (1992).
}

Table 1

Small and medium enterprises (SMEs) in Taiwan (1960-1990)

\begin{tabular}{llll}
$\begin{array}{l}\text { SMEs as a } \\
\text { proportion of all } \\
\text { manufacturing } \\
\text { firms (\%) }\end{array}$ & $\begin{array}{l}\text { SME product } \\
\text { value as a } \\
\text { proportion of all } \\
\text { manufacturing } \\
\text { output (\%) }\end{array}$ & $\begin{array}{l}\text { Employee } \\
\text { numbers }\end{array}$ & $\begin{array}{l}\text { Average } \\
\text { employee } \\
\text { number }\end{array}$ \\
\hline 99.57 & - & 64.28 & 5.98 \\
99.28 & - & 57.30 & 7.04 \\
98.96 & 37.09 & 52.52 & 8.72 \\
98.90 & 32.27 & 53.00 & 8.79 \\
99.00 & 34.46 & 57.89 & 8.49 \\
99.24 & 41.23 & 63.82 & 7.94 \\
\hline
\end{tabular}

Source: The Industrial and Commercial Censuses of Taiwan-Fukien District of The Republic of China, various years.

Most of Taiwan's labor-intensive industries had a unique feature not found in any other country in the world; that is, Taiwan's industry was not brought forth by a few big corporations but created by various small firms producing all kinds of industrial components, which constituted a critical element of the export-oriented industry. Industrial goods could not have been developed and produced within a single factory or company, but only through a network of production (Hsia, 1988; Shieh, 1992).

How could the Taiwanese SMEs get orders and export to foreign markets? The key players here were the hundreds of trading companies that were initially Japanese, but which were gradually replaced by Taiwanese companies located in Taipei. The role of the trading companies could only be understood by being put in the context of equipment manufacturing (OEM) production chains (Hoesel, 1999). Many key foreign retailers, such as Wal-Mart, JC Penny, and others, were placing OEM orders with Taiwanese firms. In 1983, there were around 36,000 domestic trading companies in Taiwan, and most of them were located in Taipei City (Chen, 1991; Ching, 2001). It was reported that over $72 \%$ of Taiwanese shoe makers sold more than half of their products through these trading companies (Shieh, 1992).

\section{Globalization of production and city-regionalization in $1980 \mathrm{~s}$}

In the early 1980s, an acute shortage of cheap labor, land and, more importantly, the rapid economic growth rise of Southeast Asian industrializing countries and mainland China, changed the pattern of industrial development in Taiwan (Chung, 1997). The change had two dimensions: on the one hand, the government initiated an industrial upgrading process by promoting high-technology industries such as personal computing and the integrated circuit industries in the country's 
northern region, centred on the core city of Taipei; on the other hand, it triggered the emigration of Taiwanese capital in search of new cheap production factors, and broke down the existing rural-urban division of labor.

In response, the government decided to transfer hightechnology industries from USA, and upgrade the industrial structure from labor-intensive to technologyintensive. Instead of attracting the investment of major multinationals as was done by the Singaporean government, for example, Taiwan's government chose to promote domestic firms as the central actors of the process of technological upgrading. The government had to shoulder the initial risks as most of the private firms hesitated to move into these more risky sectors. The government set up key research institutions, such as the Industrial Technology Research Institute (ITRI) to bridge technology transfer, and constructed the Hsinchu Science-based Industrial Park (HSIP) to subsidize and host the new firms. The HSIP and its associated 'corridor' extended to Taipei, and was praised as one of the world's most successful technopoles (Castells and Hall, 1994; Mathews, 1997). The area became home to Taiwan's most rapidly growing microelectronics industries. The firms in these sectors, mostly small and medium-sized, collectively built up a vertically disintegrated industrial system. Local companies dominated the markets for a large and growing range of computer-related products, from notebook computers, motherboards and monitors, to optical scanners, keyboards and power supplies.

Taiwan's state-of-the-art semiconductor foundries account for two-thirds of global output. Not surprisingly, the industry has grown dramatically in the past two decades. Taiwan's IT sector now ranks third in the world, with a total output of US $\$ 34$ billion in 1998, ahead of larger nations like South Korea, and behind only the US and Japan (Saxenian and Hsu, 2001). It again demonstrated that the state could lead in the creation of industrial upgrading in Taiwan. As a result, the Taipei-Hsinchu corridor became a significant high technology city-region within a global context. The Taipei metropolis reaped great benefits from this development, including the growth of producer services industries (Ching, 2001).

At the same time, a different story was unfolding in rural industrial areas, as the state was forced to permit the outflow of industrial capacity. Thus, Taiwan was transformed from a net importer of capital, to a net exporter. Initially, the investment went to Southeast Asian countries. However, Taiwanese Foreign Direct Investment (FDI) in mainland China increased markedly after 1987, and soon overshadowed that in Southeast Asia. According to Kao (2000), between 1987-91 most Taiwanese FDI in China was committed by SMEs in labor-intensive sectors such as the plastics, footwear, toy and garment industries. Most of the trans-border firms remained connected with their suppliers and customers in Taiwan, and copied the whole production networks in the host countries (Chen, 1998). In other words, whole production networks moved from Taiwan to China to take advantage of cheap resources such as labor and land without changing the production configuration. The hollowing out of rural-based, labor intensive industries led to the restructuring of the rural-urban division of labor. Searching for new connections with emigrated businesses became the imperative for the local government of Taipei City, to reposition itself in the rearrangement of the trans-border production chains.

However, the cross-Taiwan strait investments were not welcomed by the national government. For political reasons, investment in China was not officially sanctioned. ${ }^{5}$ It raised concerns about the possibility of high value-added activities leaving Taiwan. However, waves of investment nevertheless found its way to China, beginning in South China, moving gradually to East China, and particularly the Shanghai region. By 2001, 8000 Taiwanese companies had located in the Shanghai area, and between 250,000 and 400,000 Taiwanese lived in the region (Leng, 2002). While a minority of these immigrants have settled in the region, the majority travelled back and forth across the Strait and, in so doing, built up "invisible" connections between Taiwan and mainland China. They have set up Taiwanese associations in key investment sites, such as Shanghai, Beijing and Shenzhen. These associations negotiate with both governments, and sponsor cultural interchange between Taiwanese immigrants and local communities.

\section{The rise of the interface city after the $1990 \mathrm{~s}$}

The 1990s meant the emergence of new trends of cross-border investment and global competition for Taipei. The struggle to become a strategic node in the global space of flow resulted in fierce rivalry between cities (Sassen, 2001; Castells, 1996). Cities sought to build up linkages with other nodes in order to tap into resources and maintain growth.

Taiwanese FDI in China, co-ordinated from Taipei, has shifted from being labor-intensive and small-scale to being technology-intensive and large-scale. ${ }^{6}$ By the end of 1999 , over US $\$ 14.5$ billion (more than $45 \%$ of total Taiwanese outward investment) was invested in China by Taiwanese investors according to a govern-

\footnotetext{
${ }^{5}$ An explicit policy of "do not rush, be patient" was stipulated by the then-president Lee Teng-hui in 1991 to discourage the expansion of cross-strait investments. Those investments that were not reported to the government would result in fines, and some of the investors were even given prison sentences.

${ }^{6}$ The average size of investment into China rose sharply from US\$ 735,000 in 1991 to $\$ 2.78$ million in 1995 (Chung, 1997).
} 
ment report which, due to its opposition to the investment, was inclined to underestimate the amount (MOEA, 1999). At the early stage, most of the Taiwanese investors adopted a strategy of vertical division of labor across the Taiwan Strait: the technology-intensive sectors, which produced critical components, remained in Taiwan, and the labor-intensive sectors which processed final products, located in China. However, as more Taiwanese downstream assemblers moved to China, and more materials were locally sourced, the ratio of imports from Taiwan declined to about 30\% in 1998 (MOEA, 1999). More technology-intensive sectors started to move to China after the mid-1990s. Among the new cross-border investments, Shanghai City and its neighboring region hosted most of the Taiwanese high technology investors, as shown in Fig. 1.

In response to the new situation, Taiwan's businesses in general, and those in Taipei City in particular, had to manage the connections with other nodes such as Shanghai and Silicon Valley, and at the same time, embrace high value-added activities in the extension of cross-border production chains. On the one hand, the Taipei-Hsinchu corridor benefited from the interdependencies between it and Silicon Valley through a community of US-educated Taiwanese engineers who

\section{Taiwanese IC Industry Investment in Mainland China}

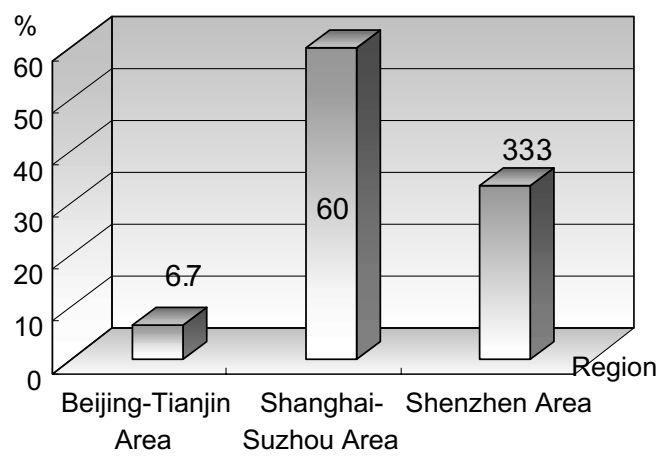

Taiwanese Notebook Computer Industry Investment in Mainland China

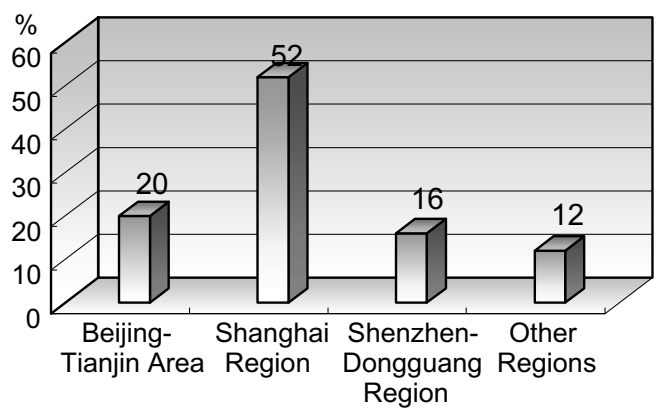

Fig. 1. The geographical distribution of Taiwanese IC \& Notebook Computer Investments in Mainland China. (Source: Capital Business Group (2001), pp. 23-24, 56-58.) coordinated a decentralized process of reciprocal industrial upgrading by transferring capital, skill, and know-how to Taiwan and by facilitating collaborations between specialist producers in the two regions. ${ }^{7}$ This transnational technical community allows distant producers to specialize and collaborate to upgrade their capabilities, particularly when the collaborations require close communications and joint-problem solving. The trust and local knowledge that exists within technical communities, even those that span continents, provides a competitive advantage in an environment where success depends on being very fast to market (Saxenian and Hsu, 2001). It underscores the role of Taipei-Hsinchu corridor as a regional motor within worldwide economic competition by aligning itself more with other global nodes than with other regions in Taiwan. Through such a process, territoriality was realigned and rescaled. Taipei became the leading actor in handling the economic growth of the city-region, and contained the headquarters of over $70 \%$ of Taiwan's top 50 informatics firms (see Fig. 2), and more than $60 \%$ of the industrial patents were created in the TaipeiHsinchu Region between 1980 to 2000 (MOEA, 2001).

Furthermore, to meet the challenge of the loss of the high-technology production that had relocated to China, an attempt was made to upgrade Taipei's producer service provision. As shown by Ching (2001), the share of product value of producer service industries, such as marketing, logistics, advertising, legal services and trading services, increased in terms of the total value produced in Taipei from 19.8\% in 1981 to $29.0 \%$ in 1996. It demonstrated that the expansion of informatics FDI in China enhanced rather than weakened the connection with the parent firms in Taipei. As more Taiwanese subcontracting firms upgraded from Original Equipment Manufacturing to original design manufacturing $(\mathrm{ODM}){ }^{8}$ and imported critical parts from Taiwan to China for processing (Hobday, 2001), the service activities supporting the cross-border manufacturing chains would create more business opportunities for the headquarters in Taipei City-region.

It seemed a new role was emerging for Taipei City in the global economy. The particularity of Taipei City in

\footnotetext{
${ }^{7}$ In the early 1980s, HSIP attracted only a handful of returnees each year. In 1990, the Park had attracted 422 returnees cumulatively. By 1997 the cumulative total had increased fivefold to over 2850 - with an average of 350 returning per year (HSIP, 1998.) Moreover, these returnees are disproportionately likely to start their own businesses. Almost half of the companies in the Science Park (97 companies) in 1997 were started by US-educated engineers, many of whom had considerable managerial or entrepreneurial experience in Silicon Valley (HSIP, 1998).

${ }^{8}$ As manufacturing went on, not only might the buyers provide technological information or assistance, but the OEM firms themselves would learn and verify their technological knowledge as they moved into production, and became ODM partners.
} 

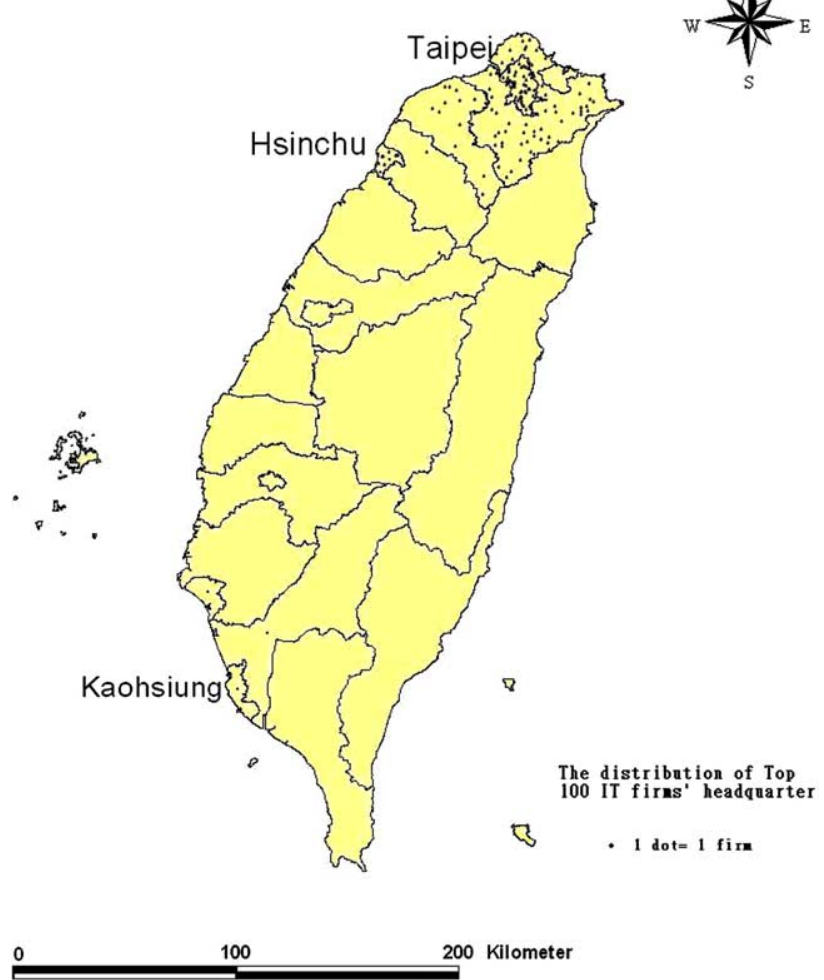

Fig. 2. The distribution of Top 100 IT firms headquarters in Taiwan. (Source: Business Next Magazine (2002), pp. 24-31.)

the global space of flows was that it constituted an interface city, which acted as a node connected to the technology hub in Silicon Valley, and which extended the high-technology investment across the Strait. It exploited the dense technical communities and complementary industrial structures within Silicon Valley and its accumulated knowledge base developed over more than two decades of technological learning (Hsu and Saxenian, 2000). ${ }^{9}$ In addition, the ethnic ties and cultural affinity between Taiwan and China facilitated cross-border investment and made exploring the market in China relatively easy (Hsing, 1998; Hsu, 2004). For example, Warburg Pincus, an American venture capital (VC) company, has entered a strategic alliance with Taiwanese counterparts to develop the Chinese market. One crucial goal of Warburg Pincus was to exploit the advantage of Taiwanese VC's knowledge of China's rapid development of high-technology industries, and

\footnotetext{
${ }^{9}$ Taiwan's technological achievements are reflected in international comparisons of patenting. While all the Asian newly industrializing economies ranked low in the 1980s, Taiwan received US patents at an accelerating rate in the 1990s and surpassed not only Singapore but also Korea and Hong Kong in the number of patents granted per capita. In fact Taiwan, along with Israel, now ranks ahead of all of the G7 except the US and Japan in patents per capita (Trajtenberg, 1990; Ching, 2002).
}

promote cooperative opportunities between the hightechnology firms across the Taiwan Strait (Lin, 2000).

The case of Acorn Campus is particularly illustrative here. The company was mainly established by a team of successful Taiwanese VCs and engineers based in Silicon Valley. It plans to introduce the incubator model to Shanghai (providing seed money, business experience, and industrial space) to encourage returnees to start up companies, focusing on semiconductor design, wireless infrastructure, and system and software development. It aims to exploit the best resources from different locations: R\&D, new product development and marketing in the US; high end logistics, design and manufacturing in Taiwan; and low cost engineering and manufacturing talent in China (Saxenian, 2002). A further example is the case of WI Harper, a VC company registered in Silicon Valley with major funds sourced from Taiwan. It assembled a fund of about US\$ 30 million in 2001, allocated $20 \%$ to Taiwan, $30 \%$ to China and $50 \%$ to Silicon Valley to develop new products in biotechnology (Leng, 2002). In doing so, it will be able to mobilize a variety of talents through high technology business networks.

In other words, a triangle connection between Silicon Valley-Taipei (Hsinchu)-Shanghai is emerging and creating a pattern of capital and knowledge circulation in the nodes of transnational business networks. The power of the transnational technical community is evident, and has become a key force in shaping the global production networks. It originated in Silicon Valley and has been transferred first to Taiwan by overseas Chinese entrepreneurs (emigrated from Taiwan) and then from Taiwan (as well as directly from Silicon Valley) to China. The dense social and professional networks foster flows of technology, capital, know-how, and information within the triangle, supporting entrepreneurship in the three regions while also providing the foundation for formal inter-regional business relations such as consortia, joint-ventures, and partnerships.

In most cases, the cross-Pacific collaboration would involve not only Silicon Valley and China but also an intermediary role played by Taiwan's high technology investors. These connections were imperative for one another, as the technology advantage rendered Taiwanese high-technology FDI profitable, and the cultural advantage attracted more Silicon Valley firms to collaborate with Taiwanese to enter China's market. ${ }^{10}$ Taipei City could grow as a city for knowledge orientation and producer services in the transformation after 1990s.

\footnotetext{
${ }^{10}$ In a questionnaire conducted by Taiwan's Ministry of Economic Affairs, $81.9 \%$ of Informatics firms agreed that the huge potential market in China was the key in attracting Taiwanese investors. In addition, $73.5 \%$ of the correspondents thought of the requests by IPOs of the key buyers was one of the major forces in pushing them to move operations across the Strait (MOEA, 1999).
} 
However, a number of governance contradictions lay across the triangle connection.

\section{The governance of the interface city}

Urban competitiveness in the global knowledge economy resides both in 'hard' (physical) and - especiallysoft (social interaction) networks (Malecki, 2002). Therefore, the key to enhancing Taipei's competitive advantage would hinge on preparing infrastructure and, more importantly, operating networks at the global, national, regional and local scales, that would gather knowledge via social interaction. As it involved the agents from different levels, the coordination and regulation of the rescaling process is a challenge for every engaged individuals to negotiate. Some issues, such as the tension between different levels of governments, the articulation and disarticulation of different regions to the global economy, were particularly problematic. However, each region had to build up collective order and developmental consensus to survive in the new conjuncture of networking (Scott, 1998).

First of all, production globalization and the breakup of the rural-urban industrialization model led different localities in Taiwan to face direct competition with barely any supportive intervention from other cities. As a result, the race for infrastructure construction became fierce, and sometimes brought about dubious investments on infrastructure in Taiwan. For example, competition for high technology parks (to attract knowledge industries) and for an international airport (for crossstrait investment) between cities in Taiwan picked up from the mid-1990s. Further competition between cities for state budget allocation cost Tapei more than one million New Taiwan dollars. ${ }^{11}$ In addition, the political conflict between the central state and the Taipei government, which was ruled by an oppositional party, caused the delay of new infrastructure construction in Taipei City. ${ }^{12}$ This caused infrastructural problems in the city. According to a report by the city government, the availability rate of sewage construction in Taipei only reached $46 \%$, even lower than Bangkok (TCG, 2001).

Secondly, the inward-looking nature of the developmental state created barriers to cross-border connec-

\footnotetext{
${ }^{11}$ Due to political confrontation between different parties, the annual budget of Taipei City was cut by $11.2 \%$ in 2001. In contrast, that of Kaoshung City increased by $16 \%$ at the same time as its mayor belonged to the ruling party. A number of key festivals supported by the central government and traditionally held in Taipei City were moved to other places under the rhetoric of "reducing regional disparity" (TCG, 2001).

${ }^{12}$ These controversies included the location and size of the stadium, the cut of subvention allocation and the dredging of the Keelung River, which flowed through the city.
}

tions. In particular, political tensions between Taiwan and China brought about interference from central government in cross-strait investments. Most of the official policies towards mainland China aimed to hinder, rather than promote, investment flows. This forced many Taiwanese investors, particularly those high-technology firms, to choose to register in a third country, such as the Cayman Islands, using 'foreign' companies to initiate their Chinese investments, rather than have to report to the Taiwanese government. In addition, the policies prevented direct linkages (in the form of trade, postal and air transportation) between Taiwan and mainland China. As a result, serving these surreptitious investments was costly, and detracted from Taipei's competitiveness (Ching, 2001).

The Taiwanese government's reluctance to permit direct linkages between Taiwan and China had affected Taipei's competitiveness in a number of ways. It usually took almost a day to travel to Shanghai from Taipei, via Hong Kong or Macau. A direct flight takes only four hours. Goods had to be detoured via a third port to arrive at their destinations in China. ${ }^{13}$ The delay in delivery was unacceptable for the management of transnational production chains. Thus, the Chairs of American and European commercial chambers in Taiwan complained about the regulations and threatened to withdrawal from Taipei, as most of the major business operation moved to mainland China. ${ }^{14}$ As a result, the membership of the American Commercial Chamber declined from 875 in early 2001 to 750 in mid-2002, whilst the European counterpart declined by 30 members over the same period. Some companies, such as Dell Computers, moved their Asian Pacific International Procurement Office from Taipei to Shanghai and other Chinese coastal cities (Kuang, 2002).

\footnotetext{
${ }^{13}$ The Taiwanese government, particularly under the pro-Taiwan independency Chen Shui-bian administration, was reluctant to unite with mainland China, and promoted the policy of "One side (of the Taiwan Strait), one country", hence prohibiting direct links across the Strait for national security reasons.

${ }^{14}$ The American Commerce Chamber represents the interests of US companies with investments in Taiwan. It engages in lobbying and conflict reconciliation. Its European counterpart played the same role for its constituent members. As Taiwan did not maintain official diplomatic relationships with the US and most European countries, the two organizations have become the key window for Taiwanese government to dialogue with their home countries respectively. Thus, the organization carried more influence in Taiwan than elsewhere. Both organizations published annual reports to assess the investment environment, and put direct pressure on the Taiwanese government. For example, Mr. Guy Wittich, the executive of the European Commercial Chamber complained that the inconvenience of not being able to connect directly led to most of the representatives of the Great China Circle, who usually located in Taipei, having to move to Hong Kong or Shanghai, as it was troublesome to frequently travel between Taipei and the other Chinese cities (Kuang, 2002).
} 
Finally, these barriers to the movement of talented people would reduce the long-term competitiveness of Taipei as an interface city. In fact, in the new economy, technical communities usually were the major carrier of tacit knowledge, which was the critical ingredient of innovation (Maskell and Malmberg, 1999), and which constitutes the competitive advantage of regions (Saxenian, 1994; Storper, 1997). Furthermore, the networks avoid the dangers of lock-in, and a more tolerant social milieu helps to ensure the connections remain diversified and innovative (Florida, 2002; Amin and Thrift, 2002). In light of these arguments, Taipei possessed both advantages and disadvantages in its connections with Silicon Valley and China. On the positive side, the work of the professional networks in Silicon Valley and the Taipei-Hsinchu corridor had demonstrated cross-fertilization between the two city-regions. The returning workforce rose dramatically in 1990s, and contributed to more than two thirds of the high-technology startups in the corridor (Hsu, 2003). Moreover, in theory, the connection between Taipei and China's prominent global cities, and Shanghai in particular, will expand the qualified engineer pool generating mutual benefits.

\section{The challenge of the interface city}

The central weakness of Taipei City as an interface city comes from the dangers of lock-in within ethnically homogenous networks. It became particularly obvious in the case of talented engineers, key elements in the production of the knowledge-based economy (Florida, 2002). As Dai (2002) points out, by 2000 there were still less than 500 foreign engineers working in Taipei. The low numbers of foreign skilled labor can be attributed to the return of overseas Taiwanese engineers, thereby reducing the requirement for foreign talent to fill labour gaps. Nevertheless, the absence of overseas skilled labour and their embodied knowledge, particularly in the telecommunication sector, would cause concerns for competitiveness in the volatile world market (Best, 1990).

The domestic companies also constituted the majority of corporate headquarters in Taipei City. Of the 105 multinationals to set up Asian corporate headquarters in the city, only one was from outside Taiwan. In other words, Taipei City's role as a corporate headquarters was to co-ordinate Taiwanese companies' crossStrait investments.

Another concern arose in the movement of skilled labour between Taipei and Shanghai. For political reasons, the Taiwanese government tried to restrict the flow of engineers between Taiwan to China. However, attempts to restrict this movement failed. Going to Shanghai has become a leading option for Taiwanese engineering graduates (Leng, 2002). It was reported that
Semiconductor Manufacturing International Corporation (SMIC), the largest and advanced Chinese semiconductor firm in Shanghai, recruited over 300 engineers from the ex-employees of Taiwan Semiconductor Manufacturing Corporation (TSMC), Taiwan's largest IC firm. It was estimated that thousands of Taiwanese engineers and skilled labor worked in China. However, the accumulated number of mainland Chinese high-technology workers working in Taiwan reached 730 by the end of September 2000 (Leng, 2002). Restrictions on the free exchange of talented labour would damage Taipei as an interface city.

In addition to the problem of labour migration, the direct connection between Silicon Valley and Shanghai threatens Taipei City's role as an interface city. Mainland Chinese are now the largest and fastest growing group of foreign-born students in US universities, with 54,466 students (or $10.5 \%$ of the total) enrolled in 1999-2000 (Saxenian, 2002). Chinese policymakers have recognized the opportunity to tap this pool of foreigneducated technology professionals for domestic development purposes. Over the past decade, governments at both local and central levels have pursued two strategies in their efforts to counteract the brain drain from China. Firstly, following Taiwan's model, Chinese agencies sought to increase professional connections and communications with the overseas community by sponsoring study tours, conferences, joint research projects and short-term work and teaching opportunities.

Secondly, competition between municipal and provincial governments for returnees has increased significantly in recent years. Many municipal governments also established Returning Students Venture Parks (or Overseas Student Parks) within the new and high tech development zones. These parks were reserved exclusively for companies started by returnees. They offered not only low rents, tax relief, shared infrastructure and financial benefits like other science parks in China, but they also addressed the special needs of returnees, such as accelerating the bureaucratic process involved with establishing residency, to assuring access to housing and prestigious - and often bilingual - schools for their children. As China's economy continues to boom and so provides a wealth of business opportunities, more Chinese professionals will return home (Wilhelm and Biers, 2000). If this trend continues, and the political impasse across the strait remains, then Taipei's role as an interface city might fade and marginalize, unless it kept upgrading technologically or adding value in innovative ways.

\section{Conclusions}

This paper has explored the dynamics of the economic development of Taipei City in the globalization 
process. The economic base of the city-region changed dramatically after the 1980s. On the one hand, more industrial firms moved part of their operations overseas and reshuffled their transnational production networks. On the other hand, the core competitive advantage of cities and regions came not from traditional service sectors, but from occupying strategic node positions within transnational flows of capital. In contrast with other global cities in East Asian NICs, such as Seoul, Singapore, and Hong Kong, where multinationals were the key agents in the process of global transformation (Short and Kim, 1999; Yeung and Olds, 2001; Meyer, 2002), the central actors in the development of Taipei City were local SMEs, in both the traditional and high-technology sectors. With insertion into global production networks, the local firms subcontracted for foreign buyers and positioned themselves as OEM makers. ${ }^{15}$ The city's external links were relatively weak, except for the establishment of IPOs (International Procurement Offices) by key global buyers. Fortunately, the overseas Chinese technical communities in Silicon Valley provided 'external' know-how for the upgrading of industrial structures. As economic reform in China stabilized, it became the major capital outlet for Taiwanese investors. A new cross-strait ethnic connection was established.

As the global networks of goods, capital, and talents had became the norm in the world economy, connections between divergent socio-economic spaces created nodal sites that 'held down' these global flows. Interface regions emerged in the extension of global spaces of flow. Such spaces were interfaces in that they connected contrasting regions, and were able to assimilate, transmit, and expand the assets of these regions. Taipei City, therefore, profited from its role as an intermediary for capital and labour flows between Silicon Valley and China's coastal cities, and in particular the Shanghai region.

In summary, as the case of Taipei as an interface city demonstrates, the people and governments of globalizing cities in the developing countries are actively searching for ways of becoming incorporated 'into' globalization. They are eager to get connected, and aggressively take action, through industrial promotion and place marketing, to join the global 'club'.

However, there are two qualifications to this argument. Firstly, as argued by Robinson (2002), the global city discourse overemphasize external connections at the expense of the diverse dynamic social and economic forces within cities themselves. Following the exportbased model, the global city discourse focuses on the

\footnotetext{
${ }^{15}$ Moreover, the industrial policies usually targeted key sectors with subsidies and promoted domestic firms, rather than attracting multinationals to invest. See Amsden (2001) for detailed analysis on the role of the local forms in the rise of the latecomer countries.
}

cluster of producer services in serving the world economy, but does not pay enough attention to the thickly embedded institutions such as the developmental state to proactively initiate local development projects (Hill and Kim, 2000; Yeung and Olds, 2001).

Secondly, globalizing cities could be the sites of globalization from below, together with those of global capital flow. In other words, global cities are also cities of transnationalism. Cities have become places of networks of relations, which extend across national borders. Despite the assertion that the emergence of transnationalism is tied to the logic of capitalism itself, and is brought into play by the interests and needs of investors and employers in the advanced countries (Portes, 1998), the skilled labour migration constitutes an important face of globalization since it links places separated by national borders through social and cultural affiliation with groups, categories, networks, and amenities. In brief, global cities should not be just a machine, but a place for self-reflexivity (Storper, 1997).

\section{Acknowledgments}

The author is grateful for valuable comments from Prof. Chia-ho Ching and two anonymous referees. Financial support from Taiwan's National Science Council (grant \# NSC 91-2415-H-002-029-) is also highly appreciated. The usual disclaimer applies.

\section{References}

Amin, A., Thrift, N., 2002. Cities: Re-imagining the Urban. Polity, London.

Amsden, A., 1985. The state and Taiwan's economic development. In: Evans, P. et al. (Eds.), Bringing The State Back In.

Amsden, A., 2001. The Rise of the Rest: Challenges to the West from Late-industrializing Economies. Oxford University Press, Oxford.

Beaverstock, J., 2002. Transnational elites in global cities: British expatriates in Singapore's financial district. Geoforum 33, 525-538.

Best, M., 1990. The New Competition. Polity, London.

Borrus, M., 1997. Left for dead: Asian production networks and the revival of US electronics. In Barry Naughton (Ed.), The China Circle: Economics and Technology in the PRC, Taiwan, and Hong Kong.

Burt, R., 1992. Structural Holes. Harvard University Press, Cambridge.

Business Next Magazine, 2002. Special issue: Top 100 IT firms in Taiwan 36, pp. 1-121 (in Chinese).

Byrne, D., 2001. Understanding the Urban. Palgrave Press, London.

Capital Business Group, 2001. The Special Issue on Taiwanese Investment in China. Capital Business Group, Taipei (in Chinese).

Cartier, C., 2002. Transnational urbanism in the reform-era Chinese city: landscape from Shenzhen. Urban Studies 39 (9), 15131532.

Castells, M., 1996. The Rise of the Network Society. Blackwell, Oxford.

Castells, M., Hall, P., 1994. Technopoles of the World-the Making of 21st Century Industrial Complex. Routledge, London. 
Chen, Jie-xuan, 1991. Taiwan's Small and Medium Sized Enterprises and International Division of Labor. Lein-Jin Press, Taipei (in Chinese).

Chen, Tain-jy, 1998. Taiwanese Firms in Southeast Asia. Edward Elgar, Cheltenham.

Ching, Chia-ho, 2001. Globalization and the development of producer services in Taiwan's metropolises. City and Planning 28 (4), 495518 (in Chinese).

Ching, Chia-ho, 2002. Knowledge-based economic society and the opportunities for territorial development. City and Planning 29 (1), 1-20 (in Chinese).

Chung, C., 1997. Division of labor across the Taiwan Strait: macro overview and analysis of the electronics industry. In Naughton, B. (Ed.), The China Circle.

Coe, N., Bunnell, T., 2003. Spatializing knowledge communities: towards a conceptualization of transnational innovation networks. Global Networks 3 (4), 437-456.

Cooke, P., 2001. Knowledge Economies :Clusters, Learning and Cooperative Advantage. Routledge, London.

Dai, Bo-fen, 2002. Economic restructuring and international migration in Taipei Metropolis. In Proceedings of Globalizing Taipei Conference, Taipei, 13 October 2002 (in Chinese).

Daniels, P., 1993. Service Industries in the World Economy. Blackwell, Cambridge.

Dicken, P., 1998. Global Shift: Transforming the World Economy, third ed. Guilford Press, New York.

Dicken, P., Yeung, H., 1999. Investing in the future: East and Southeast Asian firms in the global economy. In: Kris Olds et al. (Eds.), Globalisation and the Asia-Pacific: Contested Territories.

Florida, R., 2002. The economic geography of talent. Annals of the Association of American Geographers 92 (4), 743-755.

Frobel, F., Heinrichs, J., Kreye, O., 1980. The New International Division of Labor. Cambridge University Press, Cambridge.

Gereffi, G., 1995. Global production systems and third world development. In Stallings, B. (Ed.), Global Change, Regional Response.

Glick Schiller, N., Basch, L., Szanton Blanc, C., 1992. Transnationalism: a new analytic framework for understanding migration. In: Nina Glick, Schiller, Linda, Basch, Cristina, Szanton-Blanc (Eds.), Toward a Transnational Perspective on Migration. New York Academy of Sciences, New York, pp. 1-24.

Granovetter, M., 1995. The Economic Sociology of Firms and Entrepreneurs. In: Alejandro, Portes (Ed.), The Economic Sociology of Immigration. Rusell Sage Foundation, New York.

Hall, P., 2000. Creative cities and economic development. Urban Studies 37 (4), 639-649.

Held, D., McGrew, A., Goldblatt, D., Perraton, J., 1999. Global Transformations: Politics, Economics and Culture. Polity, Cambridge.

Hill, R., Kim, J., 2000. Global cities and developmental states: New York, Tokyo and Seoul. Urban Studies 37, 2167-2195.

Hobday, M., 2001. The electronics industries of the Asia-Pacific: exploiting international production networks for economic development. Asian-Pacific Economic Literature 15, 13-29.

Hoesel, R., 1999. New Multinational Enterprises from Korea and Taiwan. Routledge, London.

Hsia, Chu-joe, 1988. Dependency and development in the evolution of a spatial form: the case of Chang-Hua, Taiwan. Taiwan: A Radical Quarterly in Social Studies 1 (2-3), 263-337 (in Chinese).

Hsing, You-Tien, 1998. Making Capitalism in China: The Taiwan Connection. Oxford University Press, New York.

HSIP, 1998. Yearbook of the HSIP 1998. The Administration of the HSIP, Hsinchu.

Hsu, Jinn-yuh, 2003. New firm formation and technical upgrading in Taiwanese semiconductor industry: is petty commodity production still relevant to high-technology development? In: Smart, Alan,
Smart, Josephine (Eds.), Petty Capitalists: Flexibility, Place and the Global Economy.

Hsu, Jinn-yuh, 2004. From transfer to hybridization: The changing organizations of Taiwanese PC investments in China. In: Eike, Schamp, Claes-Göran, Alvstam (Eds.), Industry in a Networked World: Making Sense of Globalization. Ashgate, Hampshire.

Hsu, Jinn-yuh, Saxenian, A., 2000. The Limits of Guanxi Capitalism: Transnational Collaboration between Taiwan and the US. Environment and Planning A 32 (11), 1991-2005.

Kao, J., 1993. The worldwide web of Chinese business. Harvard Business Review (March-April), 24-36.

Kao, C., 2000. The localization of Taiwanese investment in China and its effects on Taiwan's economy. CIER Working Paper (in Chinese)

Knox, P., Agnew, J., 1998. The Geography of the World Economy, third ed. Arnold Press, London.

Kotkin, J., 1992. Tribes: How Race, Religion, and Identity Determine Success in the New Global Economy. Random House, New York.

Kuang, Wen-chi, 2002. An interview with Mr. Guy Wittich, the executive of the European Commercial Chamber. China Times, 19 August 2002 (in Chinese).

Lambooy, J., 2002. Knowledge and urban economic development: an evolutionary perspective. Urban Studies 39 (5-6), 1019-1035.

Leng, Tse-kang, 2002. Economic globalization and IT talent flows across the Taiwan Strait: the Taipei/Shanghai/Silicon Valley Triangle. Asian Survey 42 (2), 230-250.

Levy, B., Kuo, W.-J., 1991. The strategic orientation of firms and the performance of Korea and Taiwan in frontier industries: lessons from comparative case studies of keyboard and personal computer assembly. World Development 19 (4), 363-374.

Lin, Chi-cheng, 2000. An interview with Peter Liu, the founder of Warburg Pincus. China times, 30 October 2000 (in Chinese).

Lo, F., Marcotullio, P., 2000. Globalization and urban transformations in the Asia-Pacific regions: a review. Urban Studies 37 (1), $77-111$.

Low, M., 1997. Representation unbound: globalization and democracy. In Cox, K. (Ed.), Spaces of Globalization.

Lundvall, B.-A., 1996. The social dimension of the learning economy, DRUID Working Paper 96-1.

Malecki, E., 2002. Hard and soft networks for urban competitiveness. Urban Studies 39 (5-6), 929-946.

Martin, R., 1994. Stateless monies, global financial integration and national economic autonomy: the end of geography? In: Corbridge, S., Martin, R., Thrift, N. (Eds.), Money, Power and Space.

Maskell, P., Malmberg, A., 1999. The competitiveness of firms and regions: 'ubiquitification' and the importance of localized learning. European Urban and Regional Studies 6, 9-25.

Mathews, J., 1997. A Silicon Valley of the east: creating Taiwan's semiconductor industry. California Management Review 39 (4), $26-54$.

Meyer, D., 2002. Hong Kong: global capital exchange. In: Sassen, S. (Ed.), Global Networks, Linked Cities.

Mitchell, K., 2000. Networks of ethnicity. In: Sheppard, E., Barnes, T. (Eds.), A Companion to Economic Geography.

Mody, A., 1990. Institutions and dynamic comparative advantage: the electronics industry in South Korea and Taiwan. Cambridge Journal of Economics 14, 291-314.

MOEA (Ministry of Economic Affairs), 1999. Survey on Taiwanese Manufacturing Firms' Outward Investments. MOEA, Taipei (in Chinese)

MOEA, 2001. The Database of Intellectual Property Right. Ministry of Economic Affairs, Taipei.

Ong, A., Nonini, D., 1997. Ungrounded Empires: the Cultural Politics of Modern Chinese Transnationalism. Routledge, New York.

Orru, M., 1991. The institutional logic of small-firm economies in Italy and Taiwan. Studies in Comparative International Development 26 (1), 3-28. 
Portes, A., 1998. Globalisation from below: the rise of transnational communities ESRC Transnational Communities Program Working Paper No. 1.

Redding, G., 2002. The Chinese business system of China and its rationale. Asia Pacific Journal of Management 19, 221-249.

Robinson, J., 2002. Global and world cities: a view from off the map. International Journal of Urban and Regional Research 26 (3), 531-554.

Sassen, S., 2001. The Global City: New York, London, Tokyo, second ed. Princeton University Press, Princeton.

Sassen, S., 2002. Global Networks, Linked Cities. Routledge, New York.

Saxenian, A., 1994. Regional Advantage: Culture and Competition in Silicon Valley and Route 128. Harvard University Press, Cambridge.

Saxenian, A., 2002. Transnational communities and the evolution of global production networks: the case of Taiwan, China and India. Industry and Innovation 9 (3), 183-202.

Saxenian, A., Hsu, Jinn-yuh, 2001. The Silicon Valley-Hsinchu connection: technical communities and industrial upgrading. Industrial and Corporate Change 10 (4), 893-920.

Scott, A., 1998. Regions and the World Economy. Oxford University Press, Oxford.

Scott, A., 2000. Global City-Regions: Trends, Theory, Policy. Oxford University Press, Oxford.

Shieh, G.-S., 1992. Boss Island-The Subcontracting Network and Micro-entrepreneurship in Taiwan's Development. Peter Lang Publishing, New York.

Short, J., 1996. The Urban Order. Blackwell, Oxford.

Short, J., Kim, Y., 1999. Globalization and the City. Longman, Essex.

Smith, M., 2001. Transnational Urbanism: Locating Globalization. Blackwell, Oxford.

Storper, M., 1997. The Regional World: Territorial Development in a Global Economy. Guilford, New York.

Sunley, P., 2000. Urban and regional growth. In: Sheppard, E., Barnes, T. (Eds.), A Companion to Economic Geography.

Taylor, P., 2004. World City Network: A Global Urban Analysis. Routledge, London.
Taylor, P., Doel, M., Hoyler, M., Walker, D., Beaverstock, J., 2000. World cities in the Pacific Rim: a new global test of regional coherence. Singapore Journal of Tropical Geography 21 (3), 233 245.

TCG (Taipei City Government), 2001. The White Paper of Taipei City. TCG, Taipei (in Chinese).

Trajtenberg, M., 1990. Innovation in Israel, 1968-97: a comparative analysis using patent data Working Paper No. 7022, National Bureau of Economic Research, Cambridge, MA, March 1999.

Wade, R., 1990. Governing The Market: Economic Theory and the Role of Government in East Asian Industrialization. Princeton University Press, Princeton.

Waldinger, R., Fitzgerald, D., 2004. Transnationalism in question. American Journal of Sociology 109 (5), 1177-1195.

Wilhelm, K., Biers, D., 2000. No place like home. Far Eastern Economic Review 15 (June), 72-75.

Wong, Siu-Lun, Salaff, J., 1998. Network capital: emigration from Hong Kong. British Journal of Sociology 49 (3), 358-374.

World Bank, 1993. The East Asian Miracle. Oxford, New York.

$\mathrm{Wu}, \mathrm{F}$., 2000. The global and local dimensions of place-making: remaking Shanghai as a world city. Urban Studies 37 (8), 13591377.

Yeung, Y., 2000. Globalization and Networked Societies: Urbanregional Change in Pacific Asia. University of Hawaii Press, Honolulu.

Yeung, H., Olds, K., 2001. From the global city to globalizing cities: views from a developmental city-state in Pacific Asia paper presented at the IRFD World Forum on Habitat.

Zhou, M., 1992. Chinatown: the Socioeconomic Potential of an Urban Enclave. Temple Univ. Press, Philadelphia.

Zhou, Tian-cheng, 1999. The Growth of Taiwan's Small and Medium Sized Enterprises. Lien-Jing Press, Taipei (in Chinese).

Zhou, Y., Ma, L., 2000. Economic restructuring and suburbanization in China. Urban Geography 21, 205-236.

Zhou, Y., Tseng, Y., 2001. Regrounding the "ungrounded empires": localization as the geographical catalyst for transnationalism. Global Networks 1 (2), 131-153. 